\title{
Haemophilus haemolyticus, Penicillinase Negative
}

National Cancer Institute

\section{Source}

National Cancer Institute. Haemophilus haemolyticus, Penicillinase Negative. NCI

Thesaurus. Code C123475.

Any bacterial species identified as Haemophilus haemolyticus that does not produce the enzyme penicillinase. 